

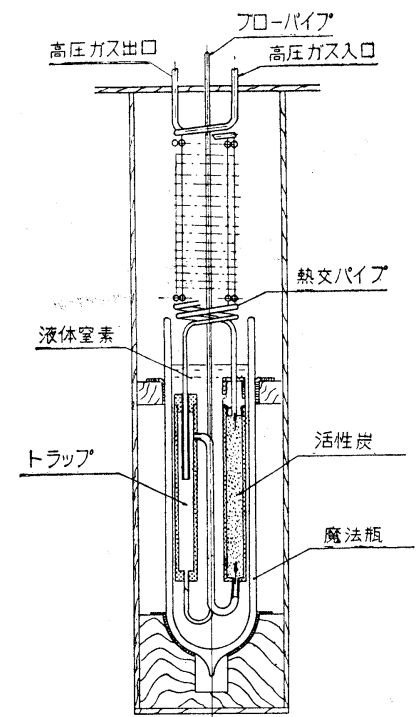
ド液化器附属）
第 1 図 ガス精製器（ガスケー

水素、ヘリウムの 液化の場合は、空気 成分も固化してガス の流路を閉塞するの で除去する必要があ る。通常液体窒素温 度に泠却した活性炭 の如き吸着剂で吸着 除去する。液化器外 に精製器を特別に設 けて事前精製するの が普通である。一例 として日本理化製力 スケード液化器附属 の精製器の構造を 第 1 図に示すが、水 素又はヘリウムガス は熱交換器で予泠さ れた後、液体窒素で 冷却された活性炭の層を通過し、そこで空気成分が吸着 除去される。同液化器には油封式のガスホルダーが付属 しているが、長期間放置すると空気成分の混入が甚だし いため、液化器運転前にガスをサイクルさせ精製を行な う。ガス純度の分析は塩化第一銅のアンモニア溶液によ りガス中の酸素成分を比色分析しているが、通常酸素濃 度 0.01 〜 $0.02 \%$ になる过精製する。

コリンズのヘリウムクライオスタットには、ネオプレ ンでシールした低圧のホールダーと加圧式の乾式ホール ダーが付属しているので、ガスの污れは少ないが、それ でも小型の活性炭精製器が付属している。

各液化器とも液化器付属の精製器にて除去し切れない 不純物は液化器中に液体窒素温度で活性炭の吸着器を置 いて除去している。

尚ヘリウムガスは、我が国では輸入しているため高価 であるので実験等に使用した後は回収しているが、空気 等の不純物の混入がかなり多くなって了うので、液化器 附属の精製器で涂去し切れず、別に回收用の精製系統 を設けるのが普通である。コリンズクライオスタットに はガス精製用のシリンダーが付属していて、このシリン ダーをクライオスタット中で、液体空気の固化点以下に 冷却して置いて、不純へリウムガスを流し、空気等の不 純物を固結除去させることが出来るようになっている。

\section{(5) 液面計}

通常の液面計と異なる点が二つ注どある。一つは低温 の液体は直接液面計で見る訳にいかないので、種々の方 法が考えられるが、確実な方法として普通は液溜底部と
頂部の差生を取り出して測定する。通常は室温の液体の マノメーターで測るが、このマノメーターがオーバース ケールしたとき、液体が差圧取出し配管に流れ込み低温 部分に達すると凍結してパイプを詰めて了うので、これ に対する対策が必要である。第二は、液体水素及び、液 体へリウムの液密度悱常に小さく $0.1 \mathrm{~g} /$ c.c. のオーダ 一である(第 1 表参照) ので、室温の液体を用いたマノ メーターでは密度の小さいものを選えでもへッド差が出 ない。そこで差圧を拡大する何等ふの手段が必要であ る。傾斜管を用いてもよいが角度が小さくなると誤差が 多いので、密度が僅かに異なる混合しない二種の液体を 用いたマノメーターを使用するとよい。一例としてカス ケード液化器に付属しているマノメーターを第 2 図に示 す。水及び密度 $0.9 \mathrm{~g} /$ c.c. $\left(30^{\circ} \mathrm{C}\right)$ の拡散 ポンプ油を 用いているので、上部の太い液溜部分と下の細いU字管 の管径を非常に違えで和けば、界面の移動による液溜部 分の液面の变動が無視出来て、液体水素の液面計として 用いた場合を例にとれば、差压は

$$
\Delta p=\left(\rho_{\mathrm{H}_{2} \mathrm{O}}-\rho_{\mathrm{oil}}\right) \Delta h=\rho_{\mathrm{H}_{2}} h
$$

で表わされ、水のみのU字管の10倍に拡大出来る筈であ る。ところが物性研究所で補正を行ったところ、上記ほ ぞ拡大出来ないことが分った。これは管径の細いための 界面張力の影響ではないかと思われるが、真因は分らな い。いずれにしても使用に当っては補正が必要と思う。

その他、断熱が非常に良いので、液溜底部の差圧管中 に液が入って来ても蒸発しない場合も正しい液面は示さ れないので、底部差圧管は第 2 図の如く、カトリ線香状 に水平に巻いてある。

液体水素、液体へリウムの液面計には上記の如く色々 の問題が多いので、他の形式、例えば電気式等考えられ るが、液体水素の場合には危険を伴うので難かしい。

コリンズクライオスタットは前号で述べた如く上部に

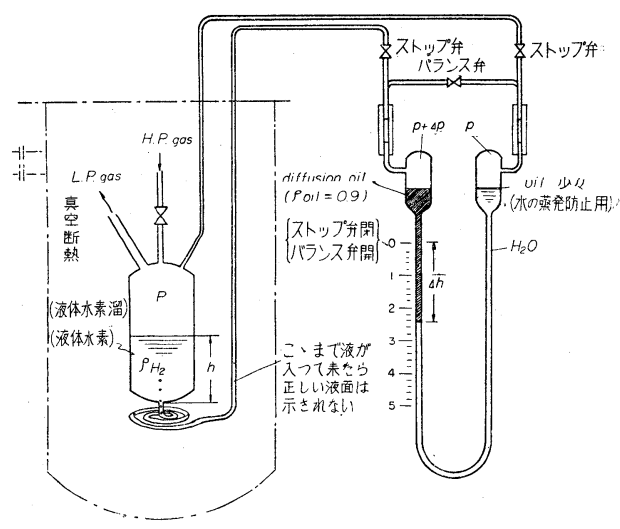

第 2 図 差圧マノメーター液面計（カスケード液 化器付属) 
のぞき空があるので夜面計はない。液化率はホールダー の下がりから計算する。液面計のある場合にもこの計算 でチエックする方が良い。

\section{2. 液体容器と汲出し}

室温との温度差が非常に大きいので相当良い断熱をし ないと蒸発損失が大きい。普通は二重壁の魔法瓶を用い る。実験用にはガラスの場合が多いが、内部を観察出来 るよう対称位置に銀鏡膜のないスリット部分をつけてい る。大量の又長時間の貯蔵用には金属魔法瓶を用いる。 液体窒素等は研究室用に良く用いられるので容器もあ りふれているが、特に低温研究を行うとこるでは大量寒 剤が必要なので 100 200 $l$ 程度の大型の 金属魔法瓶 が多くなっている。200l 金属魔法瓶を第3図に示す。

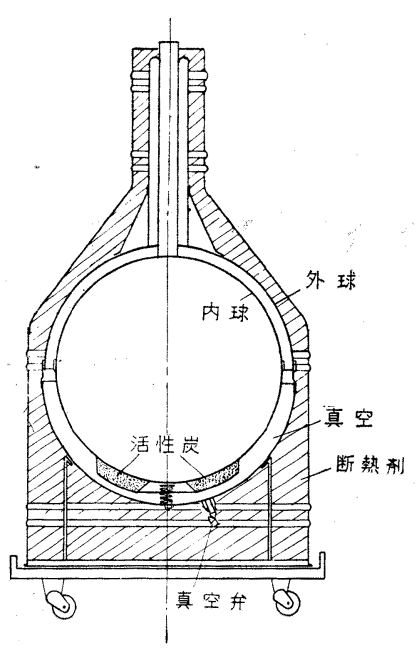

第3図 $200 l$ 金属魔法瓶 液体水素、ヘリウ ムの容器は液と室温 との温度差が大きい ので、液体窒素の中 八入れて置く。即ち 二重魔法瓶（壁の数 は4 重)である。貯 蔵用には金属二重魔 法瓶も作られている が、実験用には内容 物が見えるようにガ ラスの魔法瓶が用い られる。そして液温 度が低いので口を開 放しておくと、空気 がどえどえ固化して 壁に付着したり液中に浮遊したりするのでキャップを付 け空気を遮断し、蒸発ガス用の細い導管をつけておく。 極低温の研究ではサンプルを液温度に泠却する場合が多 いが、この場合サンプルはキャップより吊す等で魔法瓶 中に仕組んでおき、これに液体を波多出す。このような 魔法瓶もクライオスタットと呼えでいる。波出した液体 を減圧すれば更に低温のクライオスタットに出来る。一 例として筆者が物性研究所にて水素のオルソ、パラの研 究に用いたクライオスタットを第 4 図に示す。液体水素 温度で吸着剂にガスを吸着させた後、ヒーターにて脱着 させるクライオスタットである。

汲出しの場合には外側の魔法瓶 (outer dewar) に液 体空素を入れることは勿論であるが、内側魔法瓶（inner dewar) の内壁及び内容物も液体窒素で予冷する。 予冷後、液体窒素を汲出してから内部を減圧する等で、 窒素、空気を追い出して汲出す液のガスで置換してから

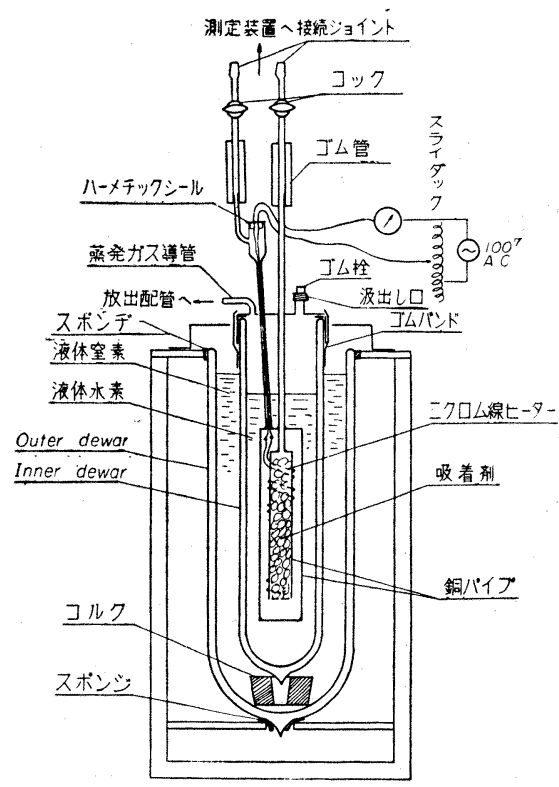

第 4 図 オルソ水素濃縮用クライオスタット（極低 温液体汲出し溶器の一例)

汲出す。こ机は残留空気成分が固化して壁に付着し、内 部観察用のスリットを曇らせることを避けるためと、液 体水素の場合は危険防止のためである。ガラスの魔法瓶 の場合は上記の如くキヤップを付けるので、内外の魔法 瓶のスリットを合せて反対側からライトで照らして液面 を観察しつつ所要量だけ没出す。特に液体へリウムの場 合は沸点が極めて低く、又蒸発潜熱が非常に小さい（第 1 表参照) ために極く僅かの熱の流入で蒸発して了うの で波出しは難かしい。又汲出す際泡立ちが甚だしく正し い液面が分らず、汲久終って泡立ちがおさまると意外に 液が少ないことが往々ある。又この場合に少し時間を経 過してから汲足てうとすると溜っていた液も蒸発してし まい却って少なくなることが多い。これは液体 $\mathrm{He}$ の蒸 発潜熱が小さいため、汲足そうとすると始めは汲出し管 が冷えていないので液が出て来ず、暖たかい蒸発ガスが 噴き出すので、溜っていた液も蒸発してしまうのである。

液の貯蔵用には金属二重魔法瓶が用いられるが、この 場合の汲出しは液面が見えないので液化器の液面計で汲 出し量をみるほかない。

貯蔵容器から他の容器へ液を移す場合はトランスファ 一・チューブでサイフォン式に貯蔵容器を加圧して行 う。液体窒素の場合はただのパイプ若しくは簡単に保冷 したものを用いるが、液体水素およびへリウムの場合 は、真空断熱したトランスフォー・チューブを用いないか と液の移動は出来ない。ガラス又は金属製の二重管の間 を真空にして封じ切るが、液の粘度が小さいので内管は 細くてよい。金属材料の場合は熱伝導の悪いステンレス 
等を選ぶ。二重管の間の一端に活性炭を入れておき、冷 却されたとき残留ガスを吸着させ真空度を上げる等が特 異な点である。

貯蔵容器も真空の問題に関係あるので他に詳しい報告 があると思うが、金属の場合は殆んど球形で両球の向い 合った面はパフ磨きし輻射を防ぐ、やはり活性炭を入れ て真空度を上げる等が要点である。

\section{3. 危険防止対策}

最も危険なものは空気と懪発性混合物をつくる水素で あるので後に詳述するが、その前に一般的に低温の液体 を扱う場合の注意を二三記すことにする。

極めて低沸点なので皮膚に触れると凍傷を起す危険が あるが、実際には液とのものを手などにかけても少時な らば平気である。こ秃は接触した瞬間に液が蒸発しガス フィルムが出来て保護するためである。むしろ液温度に 泠却したものに触わる方が危険が多いので手袋なども場 合に応じて使用すべきである。

次に汲出し容器であるが、実験用としては大抵ガラス の魔法瓶を用いるがしばしば割れることがあるので注意 を要する。ガラスは硬質の良いものを使うべきである。 特に一度使用すると器壁に水分が㠜結して了い、使用後 に水が残る。水を捨てないで低温液体を汲出すと、氷結 の際の膨脹によりガラスが壞れるので汲出す前には魔法 瓶の底に水がないことを確かめるべきである。文液体水 素温度以下の容器で、液体窒素で予冷する場合もサイフ ォンで汲出した後に大量の液体窒素が残らないよう注意 してみることが必要である。汲出しの始めに蒸発ガスの 寒冷を利用するため、汲出乙管の先を容器の底の近くま で届かせるため延長管を付けるが、ガラス管や金属管の 場合外れて底に落ち、ガラス容器を壊す場合がある。

次に液体窒素は不活性であると云う理由で最も良く用 いられているのであるから、特に危険はないが、低温液 体共通の注意として、大量の室温以上の暖かい物体に触 れると蒸発してガスになるので体積が増える（約 200 650倍）。この蒸発が急激に起ると部分的に異常に高い圧 力を生じて容器を破壊する等の危険がある。
液体ヘリウムも沸点が低いだけで不活性であると云う 点は窒素と同じである。液体酸素は水素に劣らず危険で ある。と云うのは可燃性の物質があればいつでも燃焼乃 至爆発の可能性があるからである。それ故液体酸素の容 器中や蒸発酸素ガスの中に有機物を置くことは非常に危 険である。特に油分の付着したものは絶対に近付けては ならない。又蒸発ガスは比重が大きいので地上を這って 拡がる。容器が割れたりして大量の液体酸素が放出され たような場合可燃性雲囲気になるので注意を要する。特 に酸素ガスが衣服に㳂み込んで充満している場合に着火 したりすると火だるまになり燃焼するおとれもある。こ のような時には、衣服を脱いだり消そうとしたりせず地 上を転げ迴るとよいといわれる。液体空気も空気より酸 素濃度が高いので助燃性が強い。特に液体空気の大部分 が蒸発した場合残り液中の酸素濃度は極めて高くなり、 液体酸素と変らなくなる。

水素を扱う場合は勿論最も注意が必要である。いくら 注意しても数十年に 1 回ぐらい性爆発事故が起るもので あると云う人もいるくらいである。カスケード液化器を 例にとって、危険対策を述べると、初めて水素系統へ水 素を入れようとするときは、先ゔ窒素ガスにて全系統中 の空気を置換して、次に水素で窒素を置換するようにす る。運転中は配管の接続部などからの漏洩に注意し、漏 洩しても爆発性混合物を作らないように通風を良くし、 ベンチュレーターで定期的に換気してやるとよい。

又、液化器室は火気厳禁は云う迄もないが、火花を発 するようなものも極力使わないようにし、コンクリート の厚い壁で囲い、天井はスレート等の飛びやすいものに することが望ましい。

フイリップス液化器にサイクルガスとして水素を使用 する場合も同様な注意が必要である。

液体水素の減圧用及び汲出しの際容器中を減圧するポ ソプは不燃性の油を使用することはもちろえ、液化器室 外に置くことが必要と思う。液体水素を汲出して、実験 する場所若しくは貯蔵容器の置き場所の近くには屋外ま での放出配管を設け、容器からビニールチニーブ等で蒸 発ガスを放出配管へ導き屋外へ放出する。

第 1 表 低沸点液体 の諸值

\begin{tabular}{|c|c|c|c|c|c|c|}
\hline \multirow{2}{*}{ Liquid } & \multirow{2}{*}{$\begin{array}{l}\text { Boiling point at } \\
760 \mathrm{mmHg} \text { ab. }\end{array}$} & \multirow{2}{*}{$\begin{array}{l}\text { Density of boiling } \\
\text { liquid at } 760 \mathrm{mmHg} \\
\text { saturation }\end{array}$} & \multicolumn{2}{|c|}{ Heat of vaporization } & \multicolumn{2}{|c|}{$\begin{array}{l}\text { Sensible heat of gas } \\
\text { (Satd. } \longrightarrow 0^{\circ} \mathrm{C} \text { ) }\end{array}$} \\
\hline & & & $\mathrm{Kcal} / l$ & $\mathrm{Kcal} / \mathrm{Nm}^{3} \mathrm{gas}$ & Kcal/liq $\bullet l$ & $\mathrm{Kcal} / \mathrm{Nm}^{3}$ gas \\
\hline $\mathrm{O}_{2}$ & $90.2^{\circ} \mathrm{K}\left(-183.0^{\circ} \mathrm{C}\right)$ & $1.14 \mathrm{~g} / \mathrm{c} . \mathrm{c}$. & 57.0 & 71.5 & 46 & 58 \\
\hline $\mathrm{N}_{2}$ & $77.4 \quad(-195.8)$ & 0.81 & 38.5 & 58.5 & 40 & 62 \\
\hline $\mathrm{H}_{2}$ & $20.4 \quad(-252.8$ & 0.071 & 7.4 & 9.5 & 53 & 68 \\
\hline $\mathrm{He} \mathrm{I}$ & $4.2 \quad(-269.0$ & 0.125 & 0.60 & 0.86 & 42 & 60 \\
\hline
\end{tabular}


第 2 表 各物質の Debye constant

\begin{tabular}{|c|c|c|c|c|c|c|c|c|c|c|c|c|}
\hline 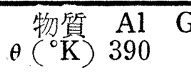 & $\begin{array}{l}\text { raphite } \\
1500\end{array}$ & $\begin{array}{c}\mathrm{Si} \\
625\end{array}$ & 40 & $\begin{array}{lr}\mathrm{Fe} & \gamma-\mathrm{F} \\
30 & 32\end{array}$ & $\begin{array}{ll}\mathrm{Fe} & \mathrm{Ni} \\
20 & 375\end{array}$ & $\begin{array}{r}\mathrm{Pt} \\
225\end{array}$ & $\begin{array}{ll}\mathrm{Cu} & \mathrm{Ag} \\
310 & 220\end{array}$ & $\begin{array}{lll}\mathrm{Au} & \mathrm{Z} \\
0 & 180 & 2\end{array}$ & $\begin{array}{lll}\mathrm{n} & \mathrm{Cd} & \mathrm{H} \\
40 & 165 & 9\end{array}$ & $\begin{array}{ccc}\mathrm{Hg} & \mathrm{Tl} & \mathrm{Ti} \\
95 & 96 & 350\end{array}$ & $\begin{array}{l}\mathrm{Zr} \mathrm{Mgg} \\
280 \& 00\end{array}$ & 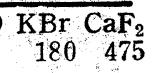 \\
\hline \multicolumn{13}{|c|}{ 第了表 特撰した物質の比熱 } \\
\hline 温度 $\left({ }^{\circ} \mathrm{K}\right)$ & $\mathrm{Al}$ & $\mathrm{Cu}$ & $\mathrm{Ni}$ & $\alpha-\mathrm{Mn}$ & $\alpha-\mathrm{Fe}$ & $\gamma-\mathrm{Fe}$ & $\mathrm{Cr}$ & $\begin{array}{l}18-8 \\
\text { ステン } \\
\text { レスa }\end{array}$ & Monelb & $\begin{array}{l}\text { Fused } \\
\text { Silica }\end{array}$ & Pyroxe & Teflon \\
\hline $20\left(\mathrm{H}_{2}\right.$ b. pt $)$ & .0024 & .0019 & .0012 & .0025 & .0011 & .0014 & \begin{tabular}{|l|l|}
.0006 \\
\end{tabular} & .0011 & .0014 & .006 & .0055 & .0183 \\
\hline 50 & .0337 & .0236 & .0164 & .0211 & 1.0129 & .0218 & .0090 & .016 & .0186 & .0272 & .0264 & .0491 \\
\hline $77\left(\mathrm{~N}_{2} \mathrm{~b} . \mathrm{pt}\right)$ & .0815 & .0471 & .0392 & .0473 & .0343 & .0487 & 7. .0277 & .038 & .0417 & .0470 & .047 & .0739 \\
\hline $90\left(\mathrm{O}_{2}\right.$ b. pt $)$ & .102 & .0554 & .0488 & .0574 & 4.0441 & .0604 & $\begin{array}{l}.0381 \\
\end{array}$ & .050 & .0509 & .0570 & .0575 & .0851 \\
\hline 100 & .116 & .0607 & .0555 & .0641 & 1.0516 & .0684 & $\begin{array}{l}4.0459 \\
4\end{array}$ & .057 & .0571 & .0643 & .065 & .0931 \\
\hline 150 & .164 & .0774 & .0785 & .0872 & 2.0775 & .0975 & 5.0757 & .085 & .0782 & .0982 & .101 & .132 \\
\hline 200 & .191 & .0854 & .0915 & .1003 & \begin{tabular}{l|l|}
.0918 \\
\end{tabular} & .1118 & 8.0925 & .099 & .0897 & .129 & .132 & .166 \\
\hline 298 & .215 & .0924 & .1060 & .1146 & 6.1070 & .1251 & 1.1073 & .114 & .1019 & .177 & .182 & $\begin{array}{l}(.248 \mathrm{at} \\
\left.280^{\circ} \mathrm{K}\right)\end{array}$ \\
\hline
\end{tabular}

a. Calculated on basis $18 \mathrm{Cr} 8 \mathrm{Ni}$ balance $\gamma-\mathrm{Fe}$, then adjusted for agreement with experimental values near room temperature. b. Calculated c. Calculated from data for $\mathrm{SiO}_{2}$ and $\mathrm{B}_{\varepsilon} \mathrm{O}_{3}$

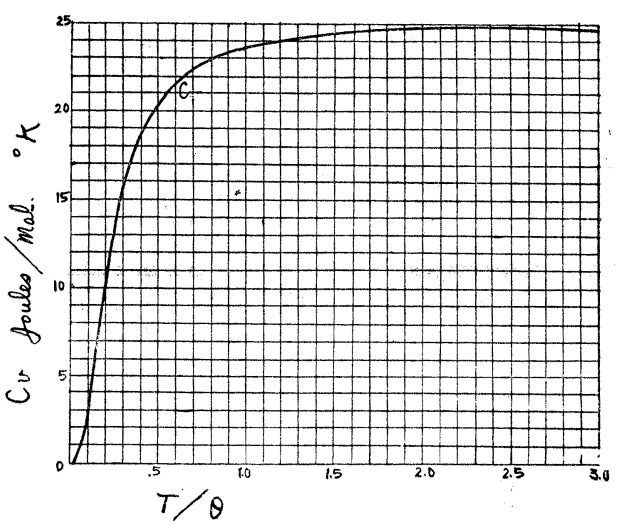

第5図 Debye の式による比熱カーヴ

液体ヘリウムは危険はないがヘリウムガスが輸入によ っているため高価なので蒸発ガス学回収する。

その他高压を使用する液化器の場合には高压一般の注 意をすることは云うまでもない。

\section{4. 物体を冷却する計算}

最後に低温の実験を行なう場合に、液化器により得た 液体を用いて、所望の装置なり資料なりを冷却しようと する場合の計算について記す(2)。

第 1 表に各液体 $1 l$ の蒸発潜熱及びそのガスが $0^{\circ} \mathrm{C}$ まで暖たまったとき奪う熱量を記す。標準状態のガス $1 \mathrm{~m}^{3}$ 当りの值も併記し、他の物性も揭げた。例えば $1 l$ 液体酸素を注入乙て装置を泠却し、蒸発ガスは $0^{\circ} \mathrm{C}$ ま で熱交換して出て来たとすれば $103 \mathrm{Kcal}$ の寒冷が冷却 に使われたことが分る訳である。

更にこれら液体を用いて冷す場合、冷される側の物質 の熱容量を計算する必要が抢こるが、これは低温になる
程比熱が小さくなるので簡単にはいかない。単結晶固体 の比熱は Debye の関係式で表わされる。固体 $\mathrm{g} \cdot \mathrm{mole}$ 当りの比熱は

$$
C_{v}=9 R(T / \theta)^{3} \int_{0}^{(\theta / T)} \frac{x^{4} e^{x}}{\left(e^{x}-1\right)^{2}} d x=3 R D(\theta / T) \cdots(1)
$$

$R$ はガス定数、 $\theta$ は物質についての固有の值で、温度 の次元を持つのでデバイ温度と呼ばれる。 $D(\theta / T)$ はデ バイ隶数である。第 5 図に $C_{v}$ と $\theta / T$ との関係をグラ フに示す。 $\theta$ がかかれば大凡の $C_{v}$ が求まる。第 2 表に デバイ温度を示す。この值は温度範囲によっては $10 \%$ 程 度誤差がでる。通常は $100^{\circ}$ から $300^{\circ} \mathrm{K}$ では良く一致 する。尚、第了表に低温で良く用いられそうな物質の比 熱の listを掲げて置く。

第 5 図又は第 3 表よりプロットした比熱カーヴを用 い、冷却しようとする温度と室温との間を積分すれば、 冷却に必要な寒泠を正確に求めることが出来る。比熱が 温度により余り変化しない範囲では、勿論平均值を採っ て計算することは差支えない。

尚極低温領域の比熱については、特異な值を示すこと が多いのでその方面の書物を参照されたい。

以上最近の液化器関係について解説したが、甚だ緾り のない雑な解説であったことをお詫びする。これから低 温它扱沶うとする方々に幾らか参考になれば幸と思う。

\section{[交献]}

（1）能瀬弘幸（東理大）、宾倉鍊（物性研究所）：「低 温度領域に於ける温度定点と二次温度計に関する研 究」、私報、1960年 3 月。一部、大島、宾倉、能瀬 : 応物関係連合講演会 (1960年 3 月 31 日) に報告。 (2) R. B. Scott “Cryogenic Engineering” 268 352 